Louisiana State University

LSU Digital Commons

Faculty Publications

Department of Geology and Geophysics

$12-1-2016$

\title{
Impact of sea-level rise on earthquake and landslide triggering offshore the Alentejo margin (SW Iberia)
}

\author{
M. C. Neves \\ Universidade do Algarve \\ C. Roque \\ Faculdade de Ciências, Universidade de Lisboa \\ K. M. Luttrell \\ Louisiana State University \\ J. T. Vázquez \\ Instituto Espanol de Oceanografia \\ B. Alonso \\ CSIC - Instituto de Ciencias del Mar (ICM)
}

Follow this and additional works at: https://digitalcommons.Isu.edu/geo_pubs

\section{Recommended Citation}

Neves, M., Roque, C., Luttrell, K., Vázquez, J., \& Alonso, B. (2016). Impact of sea-level rise on earthquake and landslide triggering offshore the Alentejo margin (SW Iberia). Geo-Marine Letters, 36 (6), 415-424. https://doi.org/10.1007/s00367-016-0459-1

This Article is brought to you for free and open access by the Department of Geology and Geophysics at LSU Digital Commons. It has been accepted for inclusion in Faculty Publications by an authorized administrator of LSU Digital Commons. For more information, please contact ir@lsu.edu. 


\title{
Impact of sea-level rise on earthquake and landslide triggering offshore the Alentejo margin (SW Iberia)
}

\author{
M. C. Neves ${ }^{1,2}$ - C. Roque ${ }^{2,3} \cdot$ K. M. Luttrell ${ }^{4}$ J. T. Vázquez ${ }^{5}$ B. Alonso ${ }^{6}$
}

Received: 4 April 2016 / Accepted: 18 July 2016 / Published online: 26 July 2016

(C) Springer-Verlag Berlin Heidelberg 2016

\begin{abstract}
Earthquakes and submarine landslides are recurrent and widespread manifestations of fault activity offshore SW Iberia. The present work tests the effects of sea-level rise on offshore fault systems using Coulomb stress change calculations across the Alentejo margin. Large-scale faults capable of generating large earthquakes and tsunamis in the region, especially NESW trending thrusts and WNW-ESE trending dextral strike-slip faults imaged at basement depths, are either blocked or unaffected by flexural effects related to sealevel changes. Large-magnitude earthquakes occurring along these structures may, therefore, be less frequent during periods of sea-level rise. In contrast, sea-level rise promotes shallow fault ruptures within the sedimentary sequence along the continental slope and upper rise within distances of $<100 \mathrm{~km}$ from the coast. The results suggest that the occurrence of continental slope failures may either increase (if triggered by shallow fault ruptures) or decrease (if triggered by deep fault ruptures) as a result
\end{abstract}

M. C. Neves

moneves@ualg.pt

1 Universidade do Algarve, Campus de Gambelas, 8005-139 Faro, Portugal

2 Instituto Dom Luiz, Universidade de Lisboa, 1749-016 Lisboa, Portugal

3 EMEPC - Estrutura de Missão para a Extensão da Plataforma Continental, Paço de Arcos, Portugal

4 Louisiana State University, Baton Rouge, LA, USA

5 Instituto Español de Oceanografía, Centro Oceanográfico de Málaga, Puerto Pesquero s/n, 29640 Fuengirola, Spain

6 Instituto de Ciencias del Mar, CSIC, GMC, P. Marítimo de la Barceloneta 37-49, 08003 Barcelona, Spain of sea-level rise. Moreover, observations of slope failures affecting the area of the Sines contourite drift highlight the role of sediment properties as preconditioning factors in this region.

\section{Introduction}

Despite their relevance for geohazard assessment, triggering mechanisms and preconditioning factors for submarine slope failure are still poorly known. Worldwide compilations of landslide ages and analyses of landslide-triggered turbidite recurrence intervals indicate that landslides are temporally random (their frequency has a Poisson distribution), and that finding is difficult to reconcile with the cyclic nature of climate-induced variations (Urlaub et al. 2013; Talling 2014; Clare et al. 2014) Some authors propose that sedimentation patterns and pore pressure buildup have a major role in triggering slope failures because of their impact on the sediment shear strength. For instance, focused compaction-driven fluid flow along permeable horizons can result in overpressure, slope failure, and slope seeps along passive margins (Dugan and Flemings 2000). Loss of sediment structure leading to rapid compaction can also generate excess pore pressures and trigger large submarine landslides (Urlaub et al. 2014a). Nevertheless, the most commonly described trigger of offshore slope failure, at least across the Mediterranean Sea and Gulf of Cadiz, are earthquakes (Urgeles and Camerlenghi 2013).

Most natural earthquakes result from tectonic processes that act at geologic timescales ( $\sim \mathrm{Ma})$. However, other processes acting at shorter timescales may induce Coulomb stress changes (as small as $0.1-1 \mathrm{MPa}$ ) capable of triggering earthquakes on faults that are already close to failure (King et al. 1994). One important class of such processes comprises the 
impacts of the climatic system on the tectonic system. Sealevel changes associated with the Milankovitch cycle may have a significant impact on the seismic cycle of nearshore faults (Luttrell and Sandwell 2010), particularly in regions of low tectonic loading rate such as west Iberia (Neves et al. 2015). Brothers et al. (2013) showed that Coulomb failure stresses across fault systems of passive continental margins may have increased more than $1 \mathrm{MPa}$ during rapid late Pleistocene-early Holocene sea-level rise, an amount sufficient to trigger fault reactivation and rupture. Those authors proposed that landslide frequency may thereby increase as a result of rising sea level, via flexural stress loading and increased seismicity rates. In contrast, it has been argued that, once realistic uncertainties in slide ages are considered, either there is no statistical relationship between rapid sea-level rise and large slide frequency, or the uncertainties in age dates are too large for such a correlation to be recognized (Urlaub et al. 2014b).

Although many different factors may precondition a slope to fail, and many different causes for failure triggering may coexist, it is important to determine under which conditions sea-level rise is a good candidate to trigger earthquakes and landslides. Neves et al. (2015) assessed the impact of sea-level rise since the last glacial maximum (LGM) on several active faults in Portugal. In the offshore area of SW Iberia, the connection between increased seismicity and ocean loading was investigated for the Horseshoe thrust fault (HSF) and the Southwest Iberian Margin (SWIM) strike-slip fault (Fig. 1). These faults belong to a vast network of NE-SW trending thrusts and WNW-ESE trending dextral strike-slip faults that accommodate the oblique convergence between Eurasia and Africa through diffuse brittle deformation (Terrinha et al.
2003; Rosas et al. 2012). The impact of sea-level rise on the Horseshoe fault was found to be extremely small, independently of the modeling parameters. The SWIM fault, on the other hand, experienced positive Coulomb stress changes $(0.25-0.75 \mathrm{MPa})$ at depths below $30 \mathrm{~km}$, which could trigger intermediate to deep earthquakes.

The present study extends the work of Neves et al. (2015) to other faults along the Alentejo margin of SW Iberia. This is a classic non-volcanic Atlantic-type margin comprising predominantly N-S and ENE-WSW trending normal fault systems developed during Mesozoic continental rifting, and which have been reactivated in the Cenozoic by inverse tectonics. There is extensive evidence of mass movements associated with these faults, as demonstrated throughout this work. Several studies in the area have considered landslides and turbidite records as proxies of paleoseismic activity (Gràcia et al. 2010; Masson et al. 2011). Recently, deep drilling during IODP Expedition 339 at Site U1391 revealed the existence of several debris flow events interbedded within the sedimentary succession of the Alentejo margin (Hernández-Molina et al. 2016). Thus, mass movement deposits along the Alentejo margin seem to be even more conspicuous than previously thought, making this an ideal setting to test the causal relationship between sea level-induced earthquakes and submarine landslides. The main objectives of this study are to (1) model the plate bending due to sea-level rise since the LGM in order to explore the possible relation between identified slope failures and sea level-induced fault ruptures, and (2) evaluate the Coulomb stresses due to sea-level rise on specific target faults, in the context of a broader search for preconditioning factors and trigger mechanisms of Holocene slope failure and mass movement.
Fig. 1 Simplified tectonic setting offshore SW Iberia including the Alentejo margin. Shaded relief: w3.ualg.pt/ jluis/mirone/data links. Fault traces: QAFI database, www.igme.

es/infoigme/applications/qafi. TAP

Tagus Abyssal Plain, HAP

Horseshoe Abyssal Plain, $G B$

Gorringe Bank, $P S F$ Pereira de

Sousa fault, $M P F$ Marquês de Pombal fault, $H S F$ Horseshoe fault, GRF Gorringe fault, SWIM

Southwest Iberian Margin fault. Small dots Epicenters $(\mathrm{Mw}>3.5)$ in the period 1964-2015 (ISC database, www.isc.ac.uk). Focal mechanisms: Pro et al. (2013). Colored dots Locations of sediment cores on HAP (Gràcia et al. 2010) and TAP (Masson et al. 2011), and of gravity cores in the MPF area (Vizcaino et al. 2006)

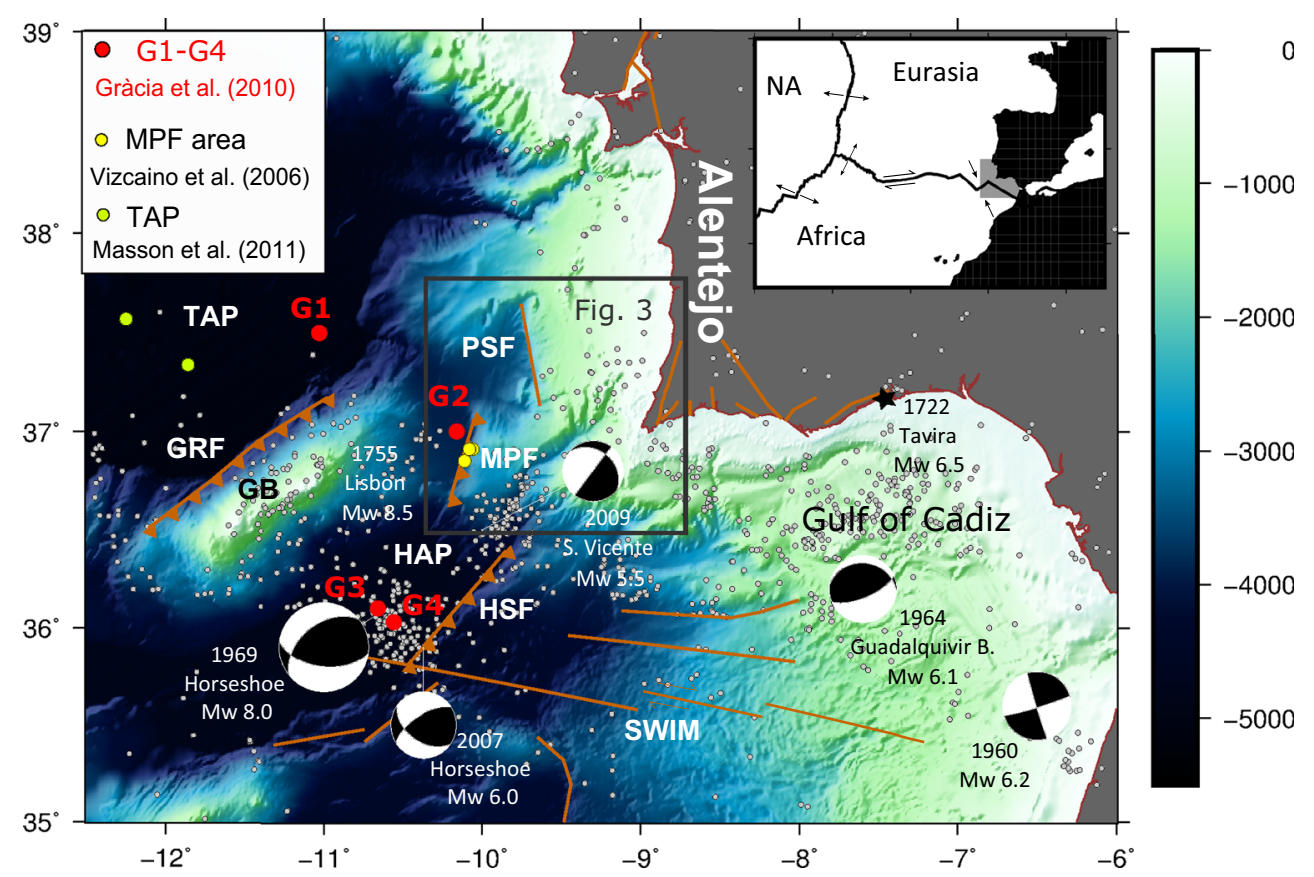




\section{Earthquakes and landslides}

Regarding seismic activity, the area offshore SW Iberia is dominated by low- to moderate-magnitude events $(\mathrm{Mw} \leq 6.0)$, although large and destructive earthquakes have nucleated here (Fig. 1). Recent data based on dense, highquality broadband networks have shown that most earthquakes occur in well-defined clusters, but only a few coincide with geologically mapped faults (Custódio et al. 2015). An important part of the instrumental seismicity occurs in the vicinity of the Horseshoe (HSF), Gorringe (GRF) and Marquês de Pombal thrust faults (MPF; Fig. 1). This is also the probable source area of the 1755 Lisbon earthquake and tsunami (Baptista et al. 2003). Fault slip rates in this region, based on thin-sheet neotectonic models, are estimated to be in the range of 1 to $2 \mathrm{~mm} /$ year (Cunha et al. 2012). These values are in agreement with low rates of tectonic loading inferred from geological data onshore western Iberia (Cabral 2012), and support the prediction of long recurrence intervals $(\sim 3,600$ years) for large-magnitude $(\mathrm{Mw}=8)$ earthquakes in the Gulf of Cadiz (Matias et al. 2013).

The largest landslides are associated with the GRF and MPF (Fig. 1). On the Gorringe Bank (GB) several slide scars have been identified on both flanks, but the largest one is located on the northern flank at 2,900 $\mathrm{m}$ water depth. This feature is related to a $225 \mathrm{~m}$ thick debris avalanche that was probably triggered by an earthquake in the late Quaternary (Iacono et al. 2012). Landslides have also been reported in the central part of the MPF, where a major slide scar has been identified at 2,575 $\mathrm{m}$ water depth. The related mass movement deposits consist of a translational slide to the north and a debris flow to the south (Vizcaino et al. 2006). Instability processes have been recognized along the Pereira de Sousa fault (PSF), an NNE-SSW normal fault inherited from Mesozoic rifting (Fig. 1; Gràcia et al. 2003; Terrinha et al. 2003). The present study reports further evidence of an extensive area of slope failure adjacent to the PSF that has been recently discovered (Roque et al. 2015). This is the area of the Sines contourite drift deposited by the Mediterranean Outflow Water circulation around the continental slope of the Alentejo margin (Hernández-Molina et al. 2016).

Evidence supporting the connection between earthquakes and landslides comes mainly from turbidite records in the Tagus (TAP) and Horseshoe abyssal plains (HAP; Fig. 1). Lebreiro et al. (1997) were the first to suggest that the emplacement of late Quaternary turbidites on the HAP was not directly linked to sea-level changes, but probably to seismic activity. Gràcia et al. (2010) applied a turbidite paleoseismology approach offshore SW Iberia for the first time along a slow-convergent margin, to determine the recurrence interval of large earthquake events during the Holocene. Turbidite paleoseismology relies on the assumption that turbidity currents that are generated simultaneously in different areas cannot be generated by purely sedimentological processes, but must have an external trigger (Goldfinger et al. 2003). In seismically active regions, the most likely trigger is a large regional earthquake. Accordingly, Gràcia et al. (2010) proposed that earthquakes are the most likely triggering mechanism for the widely separated synchronous turbidites found on the HAP and TAP. A thorough analysis of strategically located sediment cores (Fig. 1) allowed them to establish the chronology of the turbidite deposits, and to conduct a synchronicity test integrating data from previous studies (Vizcaino et al. 2006). The results revealed a record of episodic deposition of turbidites with a total of seven widespread (E1, E3, E5, E6, E8, E9, and E10) events during the Holocene (Fig. 2). Some of the most recent events correlate with the most important historical earthquakes in the area (e.g., events E1 and E3 correlate with the 1969 and 1755 earthquakes, respectively). Based on the turbidite frequency, Gràcia et al. (2010) proposed a recurrence interval of approximately 2,000 years for the large earthquakes.

Masson et al. (2011) presented further compelling evidence of seismic triggering of landslides and turbidity currents along the SW Iberian margin. Their study demonstrated that turbidites emplaced at 6,600 and $8,300 \mathrm{cal} \mathrm{yr} \mathrm{BP}$ on the TAP correlate with erosional hiatuses in two submarine canyons on the continental margin. The synchronous landslides in both canyons require regional triggers interpreted as earthquakes. On the basis of radiocarbon ages, Masson et al. (2011) associated their three youngest turbidites with events E8 (6,690 cal yr BP), E9 (7,880-8,145 cal yr BP) and E11 (10,175-10,425 cal yr BP) of Gràcia et al. (2010; Fig. 2). The only event that was directly associated with sealevel changes was E9, which occurred immediately after the 8.2 ka climatic event (Gràcia et al. 2010). However, previous events (E10, E11, E12, and E13) may also be associated with rapid sea-level changes via the impact of ocean loading on the seismic cycle of nearshore faults. Neves et al. (2015) estimated that in Portugal, even in the offshore area, the stress accumulation rate due to regular tectonic forcing is of the same order as the loading rate due to sea-level rise since the LGM. Hence, there is a plausible cause and effect link between sea level-induced earthquakes and landslides in this region.

\section{Materials and methods}

\section{Acoustic data}

Previous studies based on acoustic-backscatter maps, highresolution bathymetry, and seismic profiles already provided comprehensive interpretations of the MPF slide deposits (Gràcia et al. 2003; Vizcaino et al. 2006). Therefore, the focus of the present geomorphological analysis is on the central part of the Alentejo margin, more specifically on the area of the 


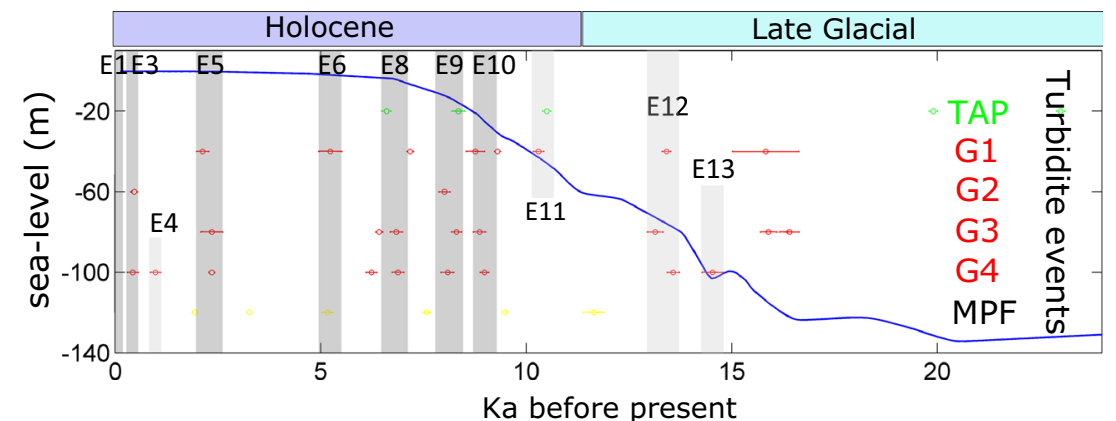

Fig. 2 Chronology of turbidite events (E3-E13) presented by Gràcia et al. (2010) based on piston cores (G1-G4) and gravity cores in the MPF area (Vizcaino et al. 2006). Darker gray bars Seven widespread turbidite events detected by Gràcia et al. (2010) in cores from at least two depositional areas. The three events recognized by Masson et al. (2011) in the TAP area correlate with E8, E9, and E11. Sea-level curve Preferred ice-volume equivalent sea-level solution from Lambeck et al. (2014)

2014 during the MOWER cruise within the framework of the CONDRIBER project, using a G-GunII airgun system $(610 \mathrm{cu}$ in with three clusters and $910 \mathrm{cu}$ in with one cluster) and shooting rate of 6.0 and $10.0 \mathrm{~s}$. The streamer SIG had three channels with 40 hydrophones each, and was $250 \mathrm{~m}$ long. The lithological information and chronostratigraphic framework of
PSF and Sines contourite drift (Fig. 3). Here, new evidence of present and past mass movements has been revealed by multibeam bathymetry and seismic reflection data.

Multibeam bathymetry data correspond to a $100 \mathrm{~m}$ cellsized grid obtained from the SWIM compilation (Zitellini et al. 2009). Seismic profile CL01 (Fig. 4) was acquired in

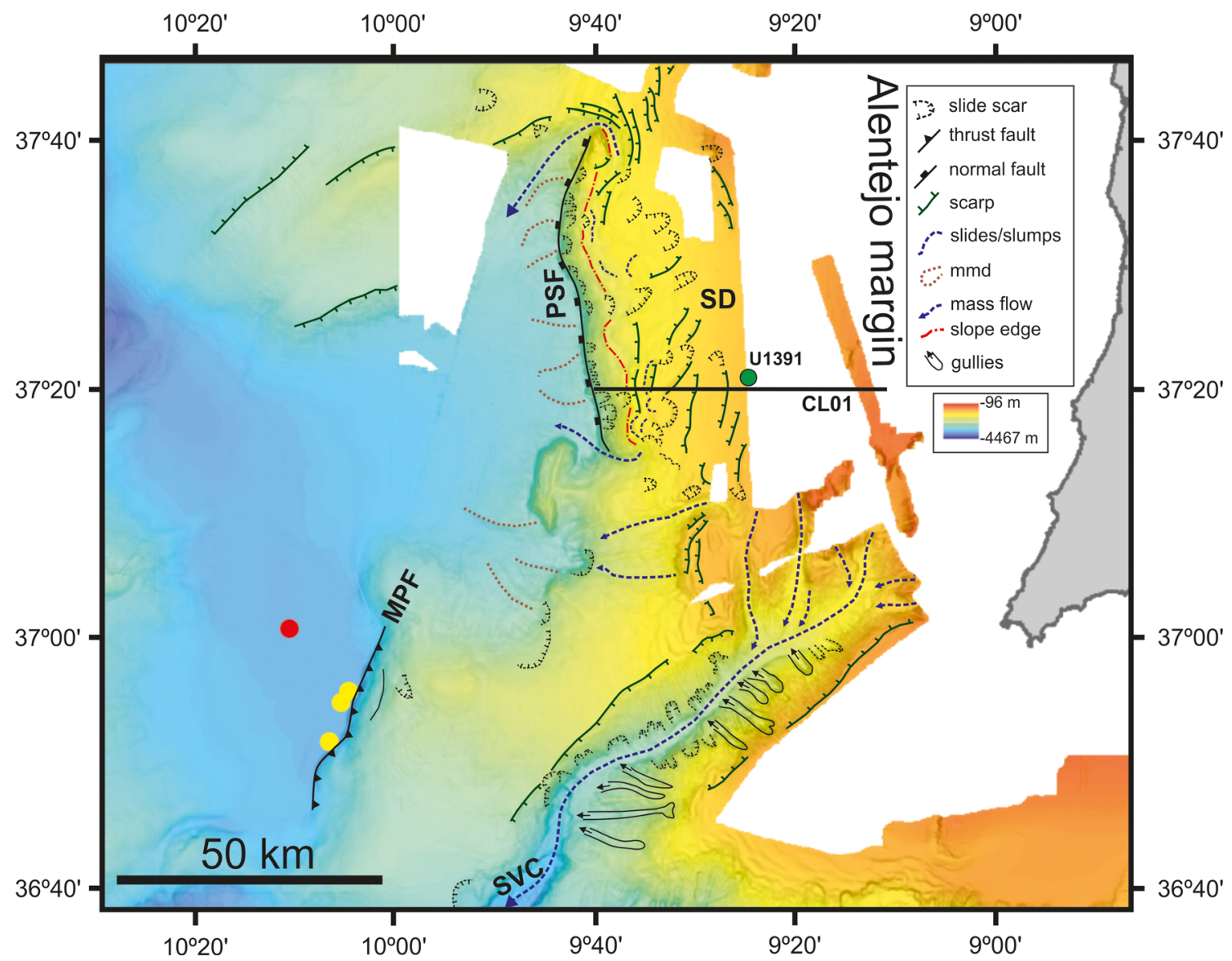

Fig. 3 Detailed SWIM multibeam bathymetry (Zitellini et al. 2009), and geomorphologic interpretation of slope failure in the Alentejo margin. $S D$ Sines contourite drift, $P S F$ Pereira de Sousa fault, $M P F$ Marquês de Pombal fault, SVC St. Vicent Canyon. The locations of Site U1391-

IODP Expedition 339 and seismic line CL01 (cf. Fig. 4) are also shown. Red and yellow dots Locations of sediment cores of Gràcia et al. (2010) and Vizcaino el al. (2006), respectively 


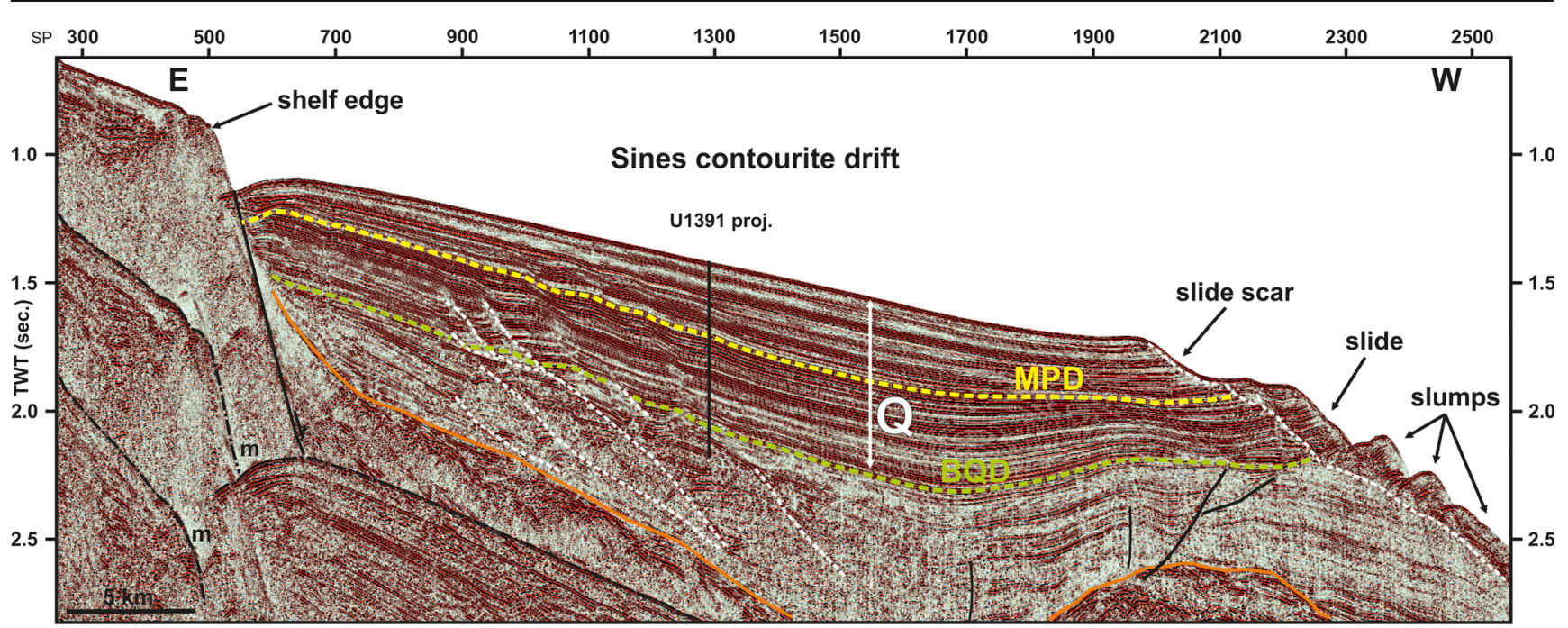

Fig. 4 Interpreted seismic line CL01 crossing the Sines Drift showing evidence of mass transport deposits (based on Hernández-Molina et al. 2016). $Q$ Quaternary, $M P D$ mid-Pleistocene discontinuity, $B Q D$ base of

the Alentejo margin were provided by IODP Expedition 339 results (Hernández-Molina et al. 2016).

\section{Flexural modeling}

The present study uses numerical models of plate flexure in response to ocean loading to evaluate the impact of sea level-induced stresses on crustal fault systems. About 21,000 years ago during the LGM, the global mean sea level was $\sim 120 \mathrm{~m}$ below the current level and it has been rising ever since (Peltier and Fairbanks 2006). To model the bending of the lithosphere in response to this vertical water load, this study considers a thick elastic plate over a Maxwell viscoelastic half-space representing the asthenosphere. The plate deflection and the 3D stress tensor are calculated using the method originally developed by Smith and Sandwell (2003) to model the earthquake cycle along the San Andreas Fault system, and later adapted to compute the ocean loading effects on nearshore fault systems (Luttrell and Sandwell 2010). Since the focus does not lie on the absolute state of stress, but rather on stress perturbations at the timescale of eustatic oscillations $\left(10^{4}-\right.$ $10^{5}$ years), stress components that act over different timescales, such as tectonic stress, are neglected. The response of an elastic plate to a surface load only involves significant bending when the wavelength of the load is comparable to the flexural wavelength of the plate. Consequently, the critical factor in the model is the elastic plate thickness (Te). The larger the elastic plate thickness, the larger the flexural wavelength and consequently, the more widespread the stress perturbations around the coastline (Neves et al. 2015).

Studies addressing the mechanical and rheological structure of the SW Iberia margin suggest mechanical coupling
Quaternary discontinuity, $m$ multiple, U1391 proj. projected Site U1391IODP Expedition 339

between the crust and upper mantle, and the existence of a strong brittle plate. Flexural models based on gravity anomalies indicate an elastic thickness of at least $30 \mathrm{~km}$ in the Gorringe Bank area (Jiménez-Munt et al. 2010), and of about 35-50 km offshore the Alentejo margin (Cunha et al. 2010). These values compare well with elastic thicknesses obtained in other oceanic areas of similar age $(\mathrm{Te}=35 \pm 15 \mathrm{~km}$ for a $140 \mathrm{Ma}$ old plate; Watts et al. 2009). The present study assumes $\mathrm{Te}=40 \mathrm{~km}$, an intermediate value within this established range. Other model parameters are the Young's modulus (70 GPa), the Poisson's ratio $(0.25)$, and the halfspace viscosity $\left(10^{20} \mathrm{~Pa}\right.$ s) corresponding to a Maxwell relaxation time of 200 years (Luttrell and Sandwell 2010). Given the load timescale $\left(\sim 10^{4}\right.$ years $)$, only the fully relaxed response of the plate is examined. Once the stress in response to ocean loading is calculated, the induced 3D stress tensor is used to estimate the seismic potential of suitably located faults.

The seismic potential of a given fault is estimated by calculating the Coulomb stress changes (King et al. 1994) given by $\Delta \sigma_{\mathrm{c}}=\Delta \tau+\mu \Delta \sigma_{\mathrm{n}}$, where $\Delta \tau$ and $\Delta \sigma_{\mathrm{n}}$ are the shear and normal stress changes on a fault plane, and $\mu$ is the effective coefficient of friction. The effective coefficient of friction incorporates the effect of pore pressure, and ranges between 0 and 0.75 for most rock types (Cocco and Rice 2002). Luttrell and Sandwell (2010) and Neves et al. (2015) have shown that uncertainties in fault parameters, such as dip angle and friction coefficient, are of second order relative to the effects of elastic plate thickness and fault location relative to the coastline. The dependence of the Coulomb stress changes on the elastic plate thickness has been computed for several fault locations by Neves et al. (2015). In general, faults affected by flexure experience linear increases in Coulomb 
stress change with increasing elastic plate thickness $\left(\Delta \sigma_{\mathrm{c}}\right.$ varying between 0.1 and $0.5 \mathrm{MPa}$ for Te varying between 25 and $55 \mathrm{~km}$ ).

\section{Results}

\section{Mass movements}

The region of the Sines contourite drift affected by slope failure is $\sim 52 \mathrm{~km}$ long and $34 \mathrm{~km}$ wide (Fig. 3). Failure is most intensive in the western sector of this drift, perched on the footwall of the PSF. In the head area, a succession of steplike scarps oriented NE-SW to NNE-SSW and extending over $15 \mathrm{~km}$ can be seen. Smaller slide scars oriented NNWSSE and as much as about $5 \mathrm{~km}$ long show the typical amphitheater shape. Several mounded bodies, interpreted as mass movement deposits, can be observed at the foot of scarps.

Seismic profile CL01 (Fig. 4) illustrates how mass movement processes affect the Quaternary sediments. The main sedimentary facies consist of calcareous muds with interbedded minor sandy layers (Hernández-Molina et al. 2016). The mass movement deposits correspond to rotational slides with stratified parallel acoustic facies and slumps with chaotic facies. The slide scar at 1,282 $\mathrm{m}$ water depth displays a concaveupward shape suggesting rotational movement.

\section{Coulomb stress}

The Coulomb stress changes are resolved along hypothetical fault planes subdivided into two main classes: (1) thin-skinned sub-vertical faults typical of sedimentary layers, striking roughly parallel to the coastline, and (2) large-scale crystalline faults affecting the basement (NE-SW trending thrusts, like the MPF and HSF, and WNW-ESE trending dextral strikeslip faults, like the SWIM lineament). The effective coefficient of friction for crystalline and thin-skinned faults are set to $\mu=0.6$ and $\mu=0.3$, respectively, as thin-skinned faults are expected to be less capable of resisting sliding. Low frictional strengths at shallow depths $(<5 \mathrm{~km})$ in sedimentary systems are commonly attributed to a combination of weak minerals within the fault zone and elevated pore pressures resulting from low fault zone permeability, particularly in shale-rich sections (Faulkner et al. 2010, and references therein). The strike, dip, and rake of the faults were selected as being predominant in the region and demonstrative of the general results (Table 1). The Coulomb stress changes allow identifying areas where rupture is promoted $\left(\Delta \sigma_{\mathrm{c}}>0\right)$ or inhibited $\left(\Delta \sigma_{\mathrm{c}}<0\right)$ during and after $120 \mathrm{~m}$ of sea-level rise.

The magnitude and sign of the Coulomb stresses depend on the depth of observation. This is mainly because the patterns of tension and compression are generally juxtaposed. Neves et al. (2015) analyzed the distribution of stress as a function of depth for the most important kinds of nearshore fault systems. The present study focuses on observation depths that are compatible with maximum fault depths inferred from seismic profiles. The Coulomb stress perturbations at thin-skinned faults are calculated at an observation depth of $3 \mathrm{~km}$, hypothetically within the sedimentary sequence (Fig. 5). However, the patterns would be very similar if other depths within the sedimentary sequence would have been chosen. Each pattern depends on the specified strike, dip, and rake, independently of the fault location, although the trace of the representative fault is depicted for reference. NW-SE trending faults experience positive perturbations near coastal areas offshore the SW Iberian margin (Fig. 5a). Conversely, NE-SW trending faults are unlikely to be reactivated, except in the eastern central area of the Gulf of Cadiz (Fig. 5b). The largest stress changes promoting shallow fault ruptures occur around the Cape St. Vicent $\left(\Delta \sigma_{\mathrm{c}} \sim 0.5 \mathrm{MPa}\right)$ within a $60 \mathrm{~km}$ wide band at approximately $80-100 \mathrm{~km}$ from the coast.

The stress perturbations at both the thrust and strike-slip crystalline faults are computed at an observation depth of $10 \mathrm{~km}$ (Fig. 5c, d). This is the maximum depth at which the NW-SE thrusts and SWIM fault are imaged in seismic reflection profiles (Terrinha et al. 2009; Zitellini et al. 2009; Rosas et al. 2012). Model results for a deeper observation depth (35 $\mathrm{km})$ can be found in Neves et al. (2015). At the depths considered here, the Coulomb stress changes are either negative or very small $(<0.2 \mathrm{MPa})$, indicating that the seismic activity related to these faults should be either unaffected or inhibited by flexural effects. Similar results are obtained for all NE-SW thrusts in the area (Horseshoe, Marquês de Pombal, and Gorringe faults), independently of the elastic plate thickness. Consequently, large-magnitude events occurring along these structures may actually be less frequent (or have longer recurrence times) during periods of sea-level rise.

In order to relate the modeled stress patterns and the mapped slope failures, the Coulomb stress changes have also been computed for a crustal section (P1, Fig. 6) across the Alentejo margin (see Fig. 5a for location). The crustal structure is based on the interpretation of the IAM5 seismic profile (Afilhado et al. 2008), selected for modeling purposes because it is amongst the longest, deepest and best studied in the region. The main fault types in P1 are (1) thin-skinned normal faults (dip $\left.=60^{\circ}\right)$ in the sedimentary layers; (2) crystalline normal faults $\left(\mathrm{dip}=60^{\circ}\right)$ in the continental crust beneath the continental shelf and slope; and (3) crystalline normal faults (dip $=120^{\circ}$ ) in the oceanic crust. All these faults are assumed to strike at directions nearly parallel to the coastline. The Coulomb stress changes calculated for these fault types are displayed at four corresponding domains numbered 1 to 3 in Fig. 6. The cross-sectional model shows that rupture is promoted for thin-skinned faults at shallow depths and inhibited for crystalline basement faults, regardless of fault dip. Thus, variations in dip angle $\left(30-80^{\circ}\right)$ are of second order relative to 
Table 1 Fault parameters used to compute Coulomb stress changes

\begin{tabular}{llllll}
\hline Region & Strike & Dip & Rake & Friction $(\mu)$ & Figure \\
\hline Sedimentary layers, normal faults & $-45^{\circ}$ & $60^{\circ}$ & $-90^{\circ}$ & 0.3 & Fig. 5a \\
& $45^{\circ}$ & $60^{\circ}$ & $-90^{\circ}$ & 0.3 & Fig. 5b \\
Crystalline crust, thrusts: MPF, HSF, GRF & $23^{\circ}$ & $35^{\circ}$ & $90^{\circ}$ & 0.6 & Fig. 5c \\
Crystalline crust, strike-slip: SWIM & $105^{\circ}$ & $90^{\circ}$ & $180^{\circ}$ & 0.6 & Fig. 5d \\
Thin-skinned, domain 1 & $20^{\circ}$ & $60^{\circ}$ & $-90^{\circ}$ & 0.3 & Fig. 6 \\
Basement, domain 2 & $20^{\circ}$ & $60^{\circ}$ & $-90^{\circ}$ & 0.6 & \\
Basement, domain 3 & $20^{\circ}$ & $120^{\circ}$ & $90^{\circ}$ & 0.6 & \\
\hline
\end{tabular}

other effects such as the fault location and orientation. Basement faults, particularly in the oceanic crust, are predicted to experience negative stress changes $\left(\Delta \sigma_{\mathrm{c}}<-0.5 \mathrm{MPa}\right)$. Across the continental slope, where the sediment thickness can be highly variable, the results for thin-skinned faults have
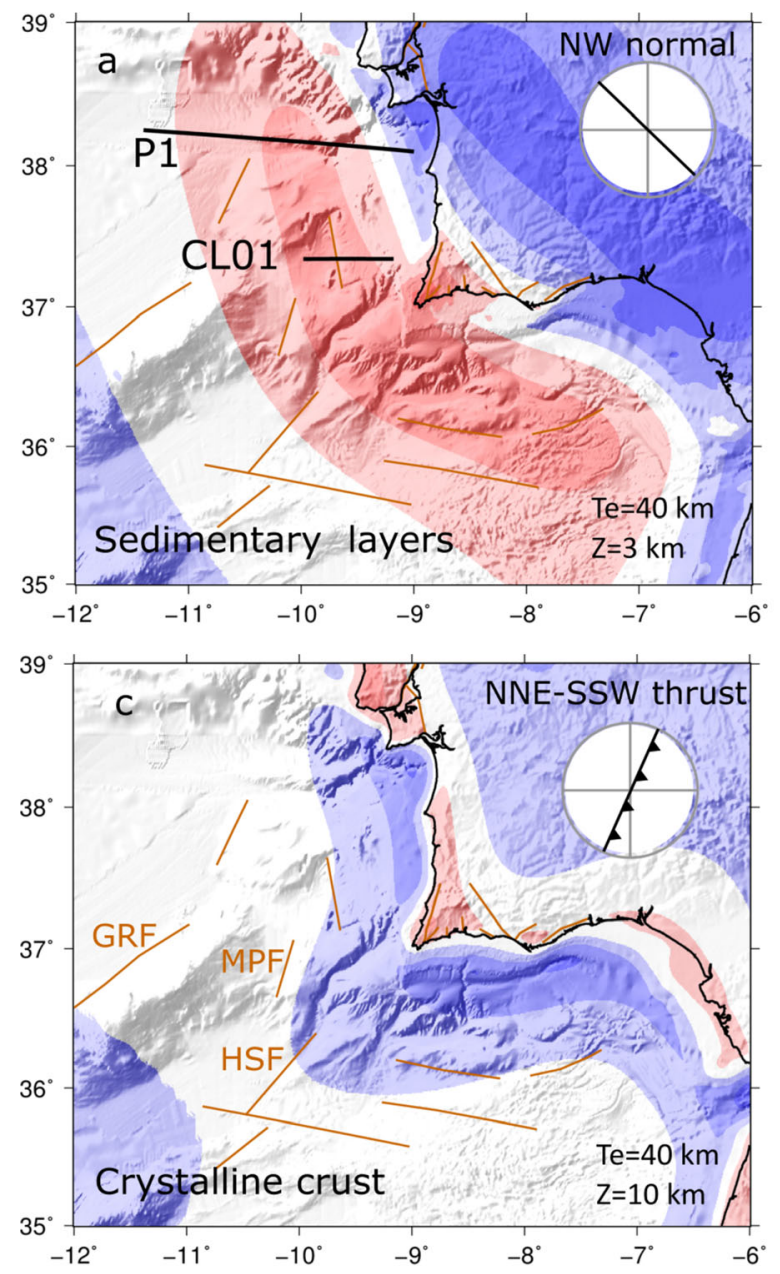

Coulomb stress change ( $\mathrm{MPa}$ )

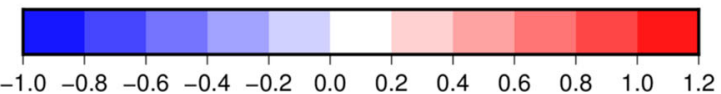

Fig. 5 Coulomb stress changes induced by sea-level rise resolved along a NW-SE and b NE-SW trending normal faults in the sedimentary layers, c NNE-SSW thrust faults (e.g., GRF, HSF, MPF) and d strikeslip (SWIM) faults in the crystalline basement. Elastic thickness (Te): 40 been extended downward and displayed down to a depth of $\sim 5 \mathrm{~km}$ (region above domain 2). The largest positive Coulomb stress changes occur in this region, within $\sim 100 \mathrm{~km}$ from the shoreline, and are maximum in the top $3 \mathrm{~km}$ at $\sim 20-80 \mathrm{~km}$ from the shelf edge.
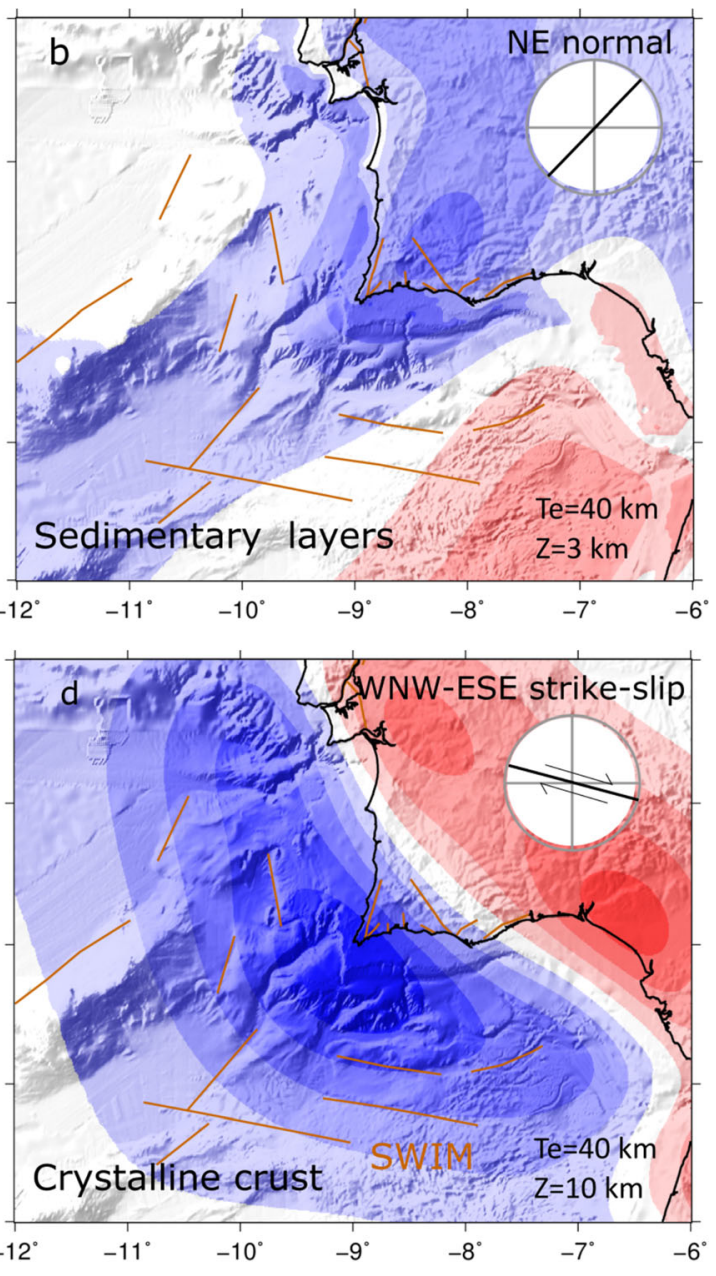

$\mathrm{km}$. Observation depth Z: $3 \mathrm{~km}$ in sedimentary layers, $10 \mathrm{~km}$ in basement. Positive (red) stress changes promote fault rupture and negative (blue) stress changes inhibit fault rupture. The location of crustal section P1 (cf. Fig. 6) to the north of seismic profile CL01 (Fig. 4) is shown in a 
Distance $(\mathrm{km})$

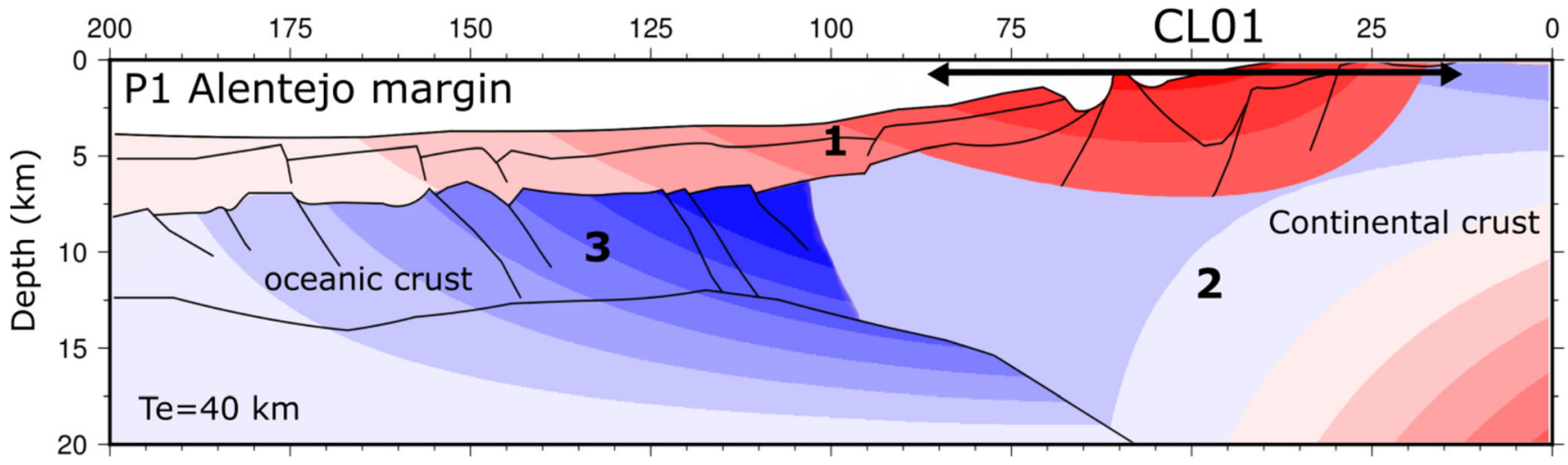

Fig. 6 Coulomb stress changes resulting from $120 \mathrm{~m}$ of sea-level rise along crustal section P1 (see Fig. 5a for location). The Coulomb stress scale bar is the same as in Fig. 5. Fault rupture is promoted in the sedimentary layers (domain 1) but inhibited in the crystalline crust.
Shallow basement faults having a lower than usual frictional resistance to slip $(\mu<0.6)$ may also be reactivated (red region above domain 2$)$. The extent of seismic profile CL01 is depicted for comparison
Extrapolation of the above results to seismic profile CL01 (Fig. 6) shows that the Coulomb stress changes are positive and practically uniform $\left(\Delta \sigma_{\mathrm{c}} \sim 0.8-1.0 \mathrm{MPa}\right)$ along the whole extent of the seismic profile. As the induced stress perturbations are uniform along a relatively large region $(\sim 100 \mathrm{~km}$ wide), it is evident that other preconditioning factors are required to explain local ruptures. Moreover, as positive perturbations of thin-skinned faults can cause only small earthquakes, the modeled flexural effects are unlikely to induce large simultaneous submarine landslides and synchronous, widely separated turbidites.

\section{Discussion and conclusions}

The analysis presented above suggests that the most plausible explanation for large-magnitude earthquakes, capable of producing widespread and synchronous turbidites, is regular tectonic loading rather than sea level-induced flexure. Largemagnitude earthquakes offshore SW Iberia are expected to be generated by major active NE-SW trending thrust faults, which are only affected by very small or even negative Coulomb stress changes (Fig. 5c). Thus, the large-scale thrust faults in the area owe their seismicity to purely tectonic earthquake cycle factors, and are probably as much a hazard today as they have been throughout the Pleistocene-early Holocene (Neves et al. 2015). However, the available evidence is insufficient to refute the link between sea-level rise and the timing and frequency of mass transport deposits. The models also show that the extra load created by sea-level rise is a good candidate to explain shallow fault ruptures (depths $<5 \mathrm{~km}$ ) in the continental slope and upper continental rise (Fig. 6). In that case, shallow translational (small) landslides coeval with small-magnitude earthquakes tend to become more frequent during and immediately after sea-level rise. This supports the argument of Brothers et al. (2013) that worldwide submarine mass transports are more numerous during the rapid late Pleistocene-early Holocene sea-level rise between 15 and 8 $\mathrm{ka}$. Shallow ruptures promoted by sea-level rise are predicted to be widespread along the continental margin. It is, therefore, possible that multiple mass transport deposits could be triggered by distinct but almost simultaneous fault ruptures. In fact, the uncertainties on the age determination (260-550 years) of the widespread turbidites sampled in the SW Iberia margin (Gràcia et al. 2010) are larger than the recurrence times of relatively small mass failures ( 40 years for failures $>1 \mathrm{~km}^{3}$ ) estimated from landslide size distributions over the Mediterranean Sea and Gulf of Cadiz (Urgeles and Camerlenghi 2013).

On the contrary, deep crystalline faults affected by negative Coulomb stress changes should have their regular seismic cycle delayed. The frequency of large earthquakes associated with deep fault ruptures is therefore expected to decrease during periods of sea-level rise. If large landslides were a direct consequence of large earthquakes, then the present results support the argument that landslides are actually less frequent during sea-level rise (or more frequent during sea-level fall). This would be in clear contradiction with Brothers et al. (2013), but in agreement with other inventories of dated submarine slides (Maslin et al. 2004; Owen et al. 2007; Lee 2009). Urgeles and Camerlenghi (2013) point out that, from the 696 mass transport deposits compiled in the Mediterranean Sea, only 70 have relatively accurate age determinations, but those available suggest that the largest failures occur during lowstand periods. They also emphasize that the database is biased toward landslide events of large magnitude, mainly because larger landslides are most easily detected and tend to attract more interest.

The statistical analysis of landslide databases also reveals that the largest slope failures occur along passive 
margins, where earthquakes of large magnitude are scarce and recurrence intervals are typically very long (Urgeles and Camerlenghi 2013; Urlaub et al. 2013). The evidence suggests that, along these margins, processes other than earthquakes that precondition the slope for failure become more important than the eventual triggering processes (Scholz et al. 2016). For instance, in the case of the Alentejo margin, the present interpretation indicates that the nature and physical properties of sediments are an important preconditioning factor. The Pliocene-Quaternary record of the Alentejo margin is dominated mostly by the deposition of contourite sediments corresponding to calcareous mud interbedded with minor sandy layers, turbidites, and debrites (HernándezMolina et al. 2016). According to Laberg and Camerlenghi (2008), the occurrence of mass movements in contourite drifts is partly favored by the composition, distribution and physical properties of the sediments themselves. These sediments are typically characterized by high sedimentation rates and high values of water content, plasticity index and porosity, which make them prone to slope failure and mass movements. This could explain, at least partially, the extensive area of the Sines contourite drift on the Alentejo margin affected by slope failure.

Moreover, since paleo-earthquakes are revealed from turbidites and mass movement deposits, their own existence is concealed behind other major potential factors controlling initiation of slope failure. According to the present results, the occurrence of landslides along the Alentejo margin may either increase (if triggered by shallow fault ruptures) or decrease (if triggered by deep fault ruptures) as a result of sea-level rise. The analysis of landslide databases searching for statistically significant patterns, trends or clusters in landslide frequency is unable to resolve this ambiguity. Instead, the search for triggering mechanisms and preconditioning factors of slope failure needs to be made locally on an individual basis. Slope stability analysis and numerical modeling is the best way to effectively determine the relative importance of endogenic (for example, steepening from tectonic, diapiric or erosional activity, excess pore pressure, the presence of weak layers, hydrate dissociation) versus exogenic (particularly earthquake loading) processes in conditioning a slope for failure. The present work reinforces the need to conduct integrated studies on specific targets offshore SW Iberia in order to establish with confidence if paleo-earthquakes are the final trigger of the observed mass movement deposits and turbidites and, if so, provide insights into the relative forcing of sea-level rise and regular tectonic loading.

Acknowledgments This research has been supported by the Portuguese Foundation for Science and Technology (FCT) through projects CONDRIBER (FCT-PTDC/GEO-GEO/4430/2012) and IDL-FCT-
UID/GEO/50019/2013. We thank the crew of R/V Sarmiento de Gamboa and the UTM-CSIC team for their help and assistance during the MOWER cruise. We highly appreciate the constructive comments of an anonymous reviewer and the journal editors, which greatly helped improving an initial version of this manuscript.

\section{Compliance with ethical standards}

Conflict of interest The authors declare that there is no conflict of interest with third parties.

\section{References}

Afilhado A, Matias L, Shiobara H, Hirn A, Mendes-Victor L, Shimamura $\mathrm{H}$ (2008) From unthinned continent to ocean: the deep structure of the West Iberia passive continental margin at 38 degrees $\mathrm{N}$. Tectonophysics 458:9-50. doi:10.1016/j.tecto.2008.03.002

Baptista MA, Miranda JM, Chierici F, Zitellini N (2003) New study of the 1755 earthquake source based on multichannel seismic survey data and tsunami modeling. Nat Hazards Earth Syst Sci 3:333-340

Brothers DS, Luttrell KM, Chaytor JD (2013) Sea-level-induced seismicity and submarine landslide occurrence. Geology 41:979-982. doi: $10.1130 / \mathrm{G} 34410.1$

Cabral J (2012) Neotectonics of mainland Portugal: state of the art and future perspectives. J Iber Geol 38:71-84. doi:10.5209/rev JIGE.2012.v38.n1.39206

Clare MA, Talling PJ, Challenor P, Malgesini G, Hunt J (2014) Distal turbidites reveal a common distribution for large $\left(>0.1 \mathrm{~km}^{3}\right)$ submarine landslide recurrence. Geology 42:263-266. doi:10.1130 /G35160.1

Cocco R, Rice JR (2002) Pore pressure and poroelasticity effects in Coulomb stress analysis of earthquake interactions. J Geophys Res 107:B22030. doi:10.1029/2000JB000138

Cunha TA, Watts AB, Pinheiro LM, Myklebust R (2010) Seismic and gravity anomaly evidence of large-scale compressional deformation off SW Portugal. Earth Planet Sci Lett 293:171-179. doi:10.1016/j. eps1.2010.01.047

Cunha TA, Matias LM, Terrinha P, Negredo AM, Rosas F, Fernandes RMS, Pinheiro LM (2012) Neotectonics of the SW Iberia margin, Gulf of Cadiz and Alboran Sea: a reassessment including recent structural, seismic and geodetic data. Geophys J Int 188:850-872. doi:10.1111/j.1365-246X.2011.05328.x

Custódio S, Dias NA, Carrilho F, Góngora E, Rio L, Marreiros C, Morais I, Alves P, Matias L (2015) Earthquakes in western Iberia: improving the understanding of lithospheric deformation in a slowly deforming region. Geophys J Int 203:127-145

Dugan B, Flemings PB (2000) Overpressure and fluid flow in the New Jersey continental slope: implications for slope failure and cold seeps. Science 289:288-291. doi:10.1126/science.289.5477.288

Faulkner DR, Jackson CAL, Lunn RJ, Schlische RW, Shipton ZK, Wibberley CAJ, Withjack MO (2010) A review of recent developments concerning the structure, mechanics and fluid flow properties of fault zones. J Struct Geol 32:1557-1575. doi:10.1016/j. jsg.2010.06.009

Goldfinger C, Nelson CH, Johnson JE, Shipboard Scientific Party (2003) Holocene earthquake records from the Cascadia subduction zone and northern San Andreas Fault based on precise dating of offshore turbidites. Annu Rev Earth Planet Sci 31:555-577

Gràcia E, Danobeitia J, Vergés J, Cordoba D, PARSIFAL Team (2003) Mapping active faults offshore Portugal $\left(36^{\circ} \mathrm{N}-38^{\circ} \mathrm{N}\right)$ : implications for seismic hazard assessment along the southwest Iberian margin. Geology 31:83-86 
Gràcia E, Vizcaino A, Escutia C, Asioli A, Rodés Á, Pallàs R, GarciaOrellana J, Lebreiro S, Goldfinger C (2010) Holocene earthquake record offshore Portugal (SW Iberia): testing turbidite paleoseismology in a slow-convergence margin. Quat Sci Rev 29: 1156-1172. doi:10.1016/j.quascirev.2010.01.010

Hernández-Molina FJ, Sierro FJ, Llave E, Roque C, Stow DAV, Williams T, Lofi J, Van der Schee M, Arnáiz A, Ledesma S, Rosales C, Rodrígues-Tovar FJ, Pardo-Igúzquiza E, Brackenridge R (2016) Evolution of the Gulf of Cadiz margin and southwest Portugal contourite depositional system: tectonic, sedimentary and paleoceanographic implications from IODP expedition 339. Mar Geol 377:7-39. doi:10.1016/j.margeo.2015.09.013

Iacono CLO, Gràcia E, Zaniboni F, Pagnoni G, Tinti S, Bartolomé R, Masson DG, Wynn RB, Lourenço N, Pinto de Abreu M, Doñobeitia JJ, Zitellini N (2012) Large, deepwater slope failures : implications for landslide-generated tsunamis. Geology 40:931-934. doi: $10.1130 / \mathrm{G} 33446.1$

Jiménez-Munt I, Fernàndez M, Vergés J, Afonso JC, Garcia-Castellanos D, Fullea J (2010) Lithospheric structure of the Gorringe Bank: insights into its origin and tectonic evolution. Tectonics 29:1-16. doi:10.1029/2009TC002458

King G, King CP, Stein RS, Lin J (1994) Static stress changes and the triggering of earthquakes. Bull Seismol Soc Am 84:935-953. doi:10.1016/0148-9062(95)94484-2

Laberg JS, Camerlenghi A (2008) The significance of contourites for submarine slope stability. In: Rebesco M, Camerlenghi A (eds) Contourites. developments in sedimentology, vol 60. Elsevier, Amsterdam, pp 537-556

Lambeck K, Rouby H, Purcell A, Sun Y, Sambridge M (2014) Sea level and global ice volumes from the last glacial maximum to the holocene. Proc Nat Acad Sci 111:15296-15303

Lebreiro SM, McCave IN, Weaver PPE (1997) Late Quaternary turbidite emplacement on the Horseshoe Abyssal Plain (Iberian Margin). J Sed Res 67:856-870

Lee HJ (2009) Timing of occurrence of large submarine landslides on the Atlantic Ocean margin. Mar Geol 264:53-64

Luttrell K, Sandwell D (2010) Ocean loading effects on stress at near shore plate boundary fault systems. J Geophys Res 115:B08411. doi:10.1029/2009JB006541

Maslin M, Owen M, Day S, Long D (2004) Linking continental slope failures and climate change: testing the clathrate gun hypothesis. Geology 32:53-56. doi:10.1130/G20114.1

Masson DG, Arzola RG, Wynn RB, Hunt JE, Weaver PPE (2011) Seismic triggering of landslides and turbidity currents offshore Portugal. Geochem Geophys Geosyst 12:Q12011. doi:10.1029 /2011GC003839

Matias LM, Cunha T, Annunziato A, Baptista MA, Carrilho F (2013) Tsunamigenic earthquakes in the Gulf of Cadiz: fault model and recurrence. Nat Hazards Earth Syst Sci 13:1-13. doi:10.5194 /nhess-13-1-2013

Neves MC, Cabral J, Luttrell K, Figueiredo P, Rockwell T, Sandwell D (2015) The effect of sea level changes on fault reactivation potential in Portugal. Tectonophysics 658:206-220. doi:10.1016/j. tecto.2015.07.023

Owen M, Day S, Maslin M (2007) Late Pleistocene submarine mass movements: occurrence and causes. Quat Sci Rev 26:958-978. doi:10.1016/j.quascirev.2006.12.011

Peltier WR, Fairbanks RG (2006) Global glacial ice volume and Last Glacial Maximum duration from an extended Barbados sea level record. Quat Sci Rev 25:3322-3337

Pro C, Buforn E, Bezzeghoud M, Udias A (2013) Mechanism of 2003, 2007 and 2009 earthquakes (S. Vicente Cape) and implications for the 1755 Lisbon earthquake.Tectonophysics 583:16-27
Roque C, Hernández-Molina FJ, Ercilla G, Casas D, Quartau R, Llave E, Alonso B, Ferran M, Mena A, Francés G, MOWER cruise party (2015) Slope failure and mass movements in the Sines Contourite Drift (West Portuguese Margin): preliminary results. In: Proc VII Symp MIA15, 21-23 September 2015, Malaga, Spain, pp 579-581

Rosas FM, Duarte JC, Neves MC, Terrinha P, Silva S, Matias L, Gràcia E, Bartolomé R (2012) Tectonophysics thrust-wrench interference between major active faults in the Gulf of Cadiz (Africa-Eurasia plate boundary, offshore SW Iberia): tectonic implications from coupled analog and numerical modeling. Tectonophysics 548-548:1-21. doi:10.1016/j.tecto.2012.04.013

Scholz NA, Riedel M, Urlaub M, Spence GD, Hyndman RD (2016) Submarine landslides offshore Vancouver Island along the northern Cascadia margin, British Columbia: why preconditioning is likely required to trigger slope failure. Geo-Mar Lett. doi:10.1007/s00367016-0452-8

Smith B, Sandwell D (2003) Coulomb stress accumulation along the San Andreas Fault system. J Geophys Res 108:2296. doi:10.1029/2002 JB002136

Talling PJ (2014) On the triggers, resulting flow types and frequency of subaqueous sediment density flows in different settings. Mar Geol 352:155-182

Terrinha P, Pinheiro LM, Henriet J-P, Matias L, Ivanov MK, Monteiro JH, Akhmetzhanov A, Volkonskaya A, Cunha T, Shaskin P, Rovere M, TTR10 Shipboard Scientific Party (2003) Tsunamigenicseismogenic structures, neotectonics, sedimentary processes and slope instability on the southwest Portuguese Margin. Mar Geol 195:55-73

Terrinha P, Matias L, Vicente J, Duarte D, Luís J, Pinheiro L, Lourenço N, Diez S, Rosas F, Magalhães V, Valadares V, Zitellini N, Roque C, Mendes-Víctor L (2009) Morphotectonics and strain partitioning at the Iberia - Africa plate boundary from multibeam and seismic reflection data. Mar Geol 267:156-174. doi:10.1016/j. margeo.2009.09.012

Urgeles R, Camerlenghi A (2013) Submarine landslides of the Mediterranean Sea: trigger mechanisms, dynamics, and frequencymagnitude distribution. J Geophys Res 118:2600-2618. doi:10.1002/2013JF002720

Urlaub M, Talling PJ, Masson DG (2013) Timing and frequency of large submarine landslides: implications for understanding triggers and future geohazard. Quat Sci Rev 72:63-82. doi:10.1016/j. quascirev.2013.04.020

Urlaub M, Talling P, Zervos A (2014a) A numerical investigation of sediment destructuring as a potential globally widespread trigger for large submarine landslides on low gradients. submarine mass movements and their consequences. Springer, Heidelberg, pp 177 188

Urlaub M, Talling PJ, Clare M (2014b) Sea-level-induced seismicity and submarine landslide occurrence: comment. Geology 42:2014-2015. doi:10.1130/G35254C.1

Vizcaino A, Gràcia E, Pallàs R, Garcia-Orellana J, Escutia C, Casas D, Willmott V, Diez S, Asioli A, Dañobeitia J (2006) Sedimentology, physical properties and age of mass transport deposits associated with the Marquês de Pombal Fault, Southwest Portuguese Margin. Norw J Geol 86:177-186

Watts AB, Rodger M, Peirce C, Greenroyd CJ, Hobbs RW (2009) Seismic structure, gravity anomalies, and flexure of the Amazon continental margin, NE Brazil. Geophys Res 114:B07103. doi:10.1029/2008JB006259

Zitellini N, Gràcia E, Matias L, Terrinha P, Abreu MA, DeAlteriis G, Henriet JP, Dañobeitia JJ, Masson DG, Mulder T, Ramella R, Somoza L, Diez S (2009) The quest for the Africa-Eurasia plate boundary west of the Strait of Gibraltar. Earth Planet Sci Lett 280: 13-50. doi:10.1016/j.eps1.2008.12.005 